\title{
Divertículo vesical
}

Vicens Vicens A, de la Cruz Ruiz M, García-Montes F, Ozonas Moragues M.

Servicio de Urología. Hospital Universitario Son Dureta. Palma de Mallorca.

Actas Urol Esp. 2008;32(10):1047

$\mathrm{P}$ aciente varón de 56 años de edad en estudio por retención aguda de orina, portador de sonda vesical permanente. Ecográficamente se observa gran HBP y masa de aspecto quístico retrovesical que persiste con vejiga vacía (Fig. 1).

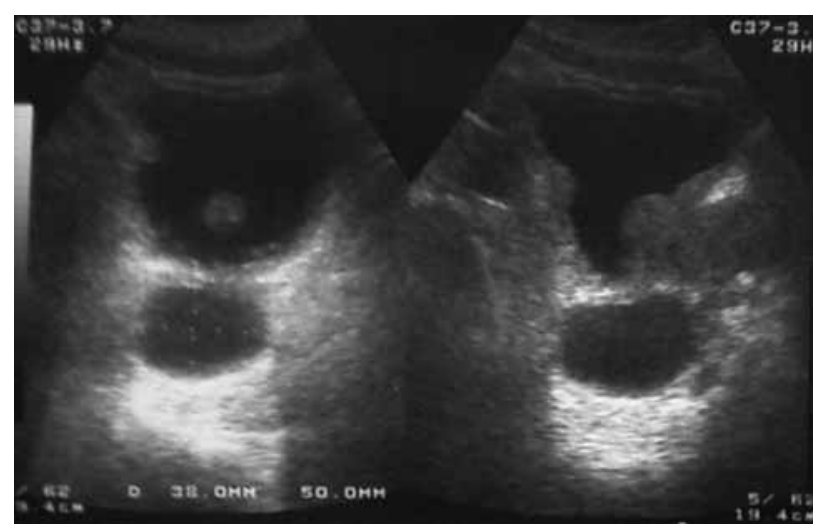

FIGURA 1

Ante el diagnóstico diferencial de la masa quística, se decide solicitar una Resonancia Magnética Nuclear en la que se observa un gran divertículo vesical de cuello estrecho dependiente de la cara posterior de la vejiga (Figs. 2A y 2B ).

En la urografía intravenosa se rellena el divertículo retrovesical, persistiendo lleno tras la fase de vaciado (Fig. 3). Buena evolución clínica tras adenomectomía y exéresis del quiste por vía transvesical.

Correspondencia autor: Dr. A. Vicens Vicens Servicio de Urologia

Hospital Universitario Son Dureta

Andrea Doria, 55 - 07014 Palma de Mallorca

Tel.: 971175000

E-mail autor: docvic24@hotmail.com

Información artículo: Imágenes en Urología

Trabajo recibido: junio 2007

Trabajo aceptado: julio 2007
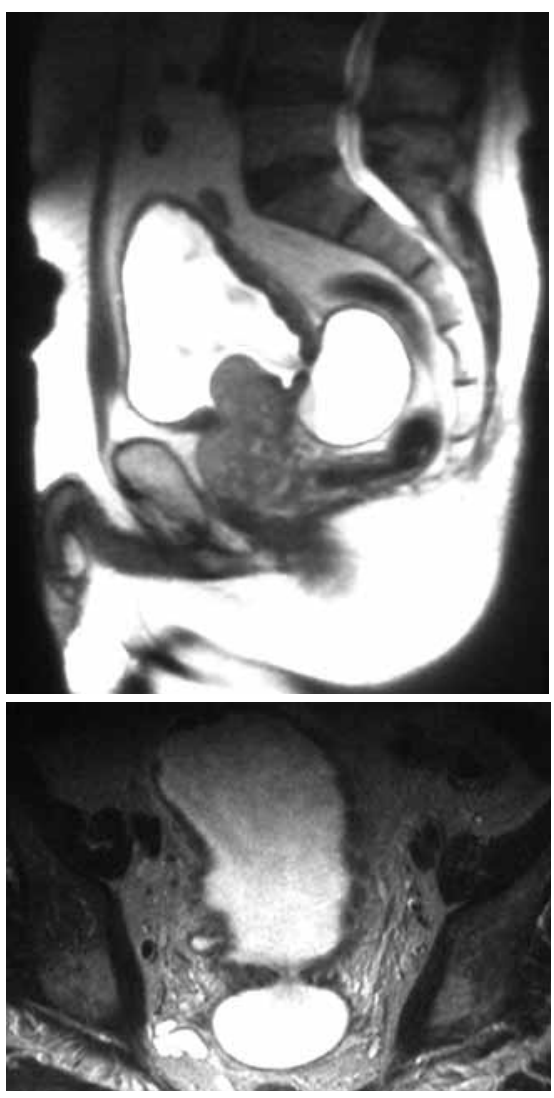

FIGURA $2 A$ y $2 B$

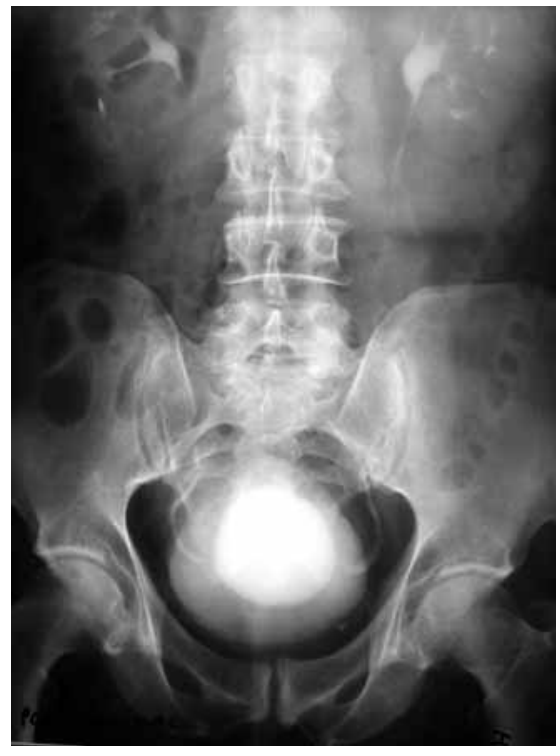

FIGURA 3 